(c) American Dairy Science Association, 2005.

\title{
Effects of Bovine Somatotropin on Uterine Genes Related to the Prostaglandin Cascade in Lactating Dairy Cows*
}

\author{
S. A. Balaguer, R. A. Pershing, C. Rodriguez-Sallaberry, \\ W. W. Thatcher, and L. Badinga \\ Department of Animal Sciences, University of Florida, Gainesville 32611
}

\begin{abstract}
Multiparous Holstein cows, averaging $80 \mathrm{~d}$ in milk, were used to examine the effect of exogenous bovine somatotropin (bST) on uterine expression of estrogen receptor $\alpha(\mathrm{ER} \alpha)$, prostaglandin endoperoxide synthase-2 (PGHS-2), and peroxisome proliferator-activated receptor $\delta(\operatorname{PPAR} \delta)$. About $12 \mathrm{~h}$ before expected ovulation in a synchronization protocol, cows were assigned to receive bST (500 $\mathrm{mg}, \mathrm{n}=11$ ) or serve as untreated controls $(n=10)$. Cows that ovulated $(n=9$ bST, 8 control) were divided within treatment to be killed on d 3 or 7 postovulation. Samples of intercaruncular endometrial tissue from uterine horns ipsilateral to the corpus luteum were collected and stored at $-80^{\circ} \mathrm{C}$ for subsequent mRNA analyses. Endometrial concentrations of ER $\alpha$ and PGHS-2 mRNA transcripts were greater on $\mathrm{d} 7$ than on $\mathrm{d} 3$ of the estrous cycle, but did not differ between treatments. Compared with untreated cows, short-term bST treatment decreased PGHS-2 protein expression at 7 of the estrous cycle. Concentration of PPAR $\delta$ mRNA transcript in the uterus decreased between $d 3$ and 7 of the estrous cycle and was negatively correlated with ER $\alpha$ and PGHS-2 mRNA concentrations. Short-term administration of bST to lactating dairy cows had minimal effects on uterine genes encoding $\mathrm{ER} \alpha$, PGHS-2, and PPAR $\delta$ at $\mathrm{d} 3$ and 7 of the estrous cycle but there may be an inverse relationship between $\operatorname{PPAR} \delta$ and uterine expression of $\mathrm{ER} \alpha$ and PGHS-2 genes.
\end{abstract}

(Key words: uterus, gene, bovine somatotropin, receptor)

Abbreviation key: $\mathbf{E R} \alpha=$ estrogen receptor alpha,
PGHS = prostaglandin endoperoxide synthase,
PPAR = peroxisome proliferator-activated receptor,
TBS = Tris-buffered saline.

Received August 25, 2004.

Accepted November 3, 2004.

Corresponding author: L. Badinga; e-mail: Badinga@animal. ufl.edu.

*This work was supported by grant 99-35203-7676 from NRI Competitive Grants Program/USDA and is published as Journal Series No. R-10520, University of Florida Agriculture Experiment Station.

\section{INTRODUCTION}

Episodic release of $\mathrm{PGF}_{2 \alpha}$ from the uterus is responsible for luteolytic signal during the estrous cycle in domestic ruminants (McCracken et al., 1972; Thatcher et al., 1984). It has been proposed that estrogens from ovarian follicles interact with estrogen receptor alpha $(\mathbf{E R} \alpha)$ to increase oxytocin receptor gene expression, which ultimately leads to pulsatile release of $\mathrm{PGF}_{2 \alpha}$ (Beard and Lamming, 1994; Kim et al., 2003). The ratelimiting step in eicosanoid synthesis is the cleavage of sn-2 fatty acyl ester bond of membrane phospholipids by cytosolic phospholipase $\mathrm{A}_{2}$ (Van den Bosch, 1980; Irvine, 1982). The arachidonic acid that is released by phospholipid hydrolysis is acted on by prostaglandin endoperoxide synthase (PGHS) to form PGH-2, which then is converted to PGF by a reductase. There are 2 forms of PGHS that have been characterized, a constitutively expressed PGHS-1, and an induced PGHS-2 (Smith et al., 1996). In cattle, the synthesis and activity of PGHS-2 must be attenuated for pregnancy to be maintained (Thatcher et al., 1997). Whether and how exogenous bST interacts with the PGF cascade in cattle has not been fully elucidated.

Peroxisome proliferator-activated receptors (PPAR) have been studied traditionally for their roles in lipid metabolism and metabolic diseases (Chinetti et al., $2000)$. There are 3 subtypes of $\operatorname{PPAR}(\operatorname{PPAR} \alpha, \delta / \beta$, and $\gamma$ ), all of which have distinct patterns of expression and functional roles (Braissant and Wahli, 1998). Subtype $\operatorname{PPAR} \alpha$ is mainly expressed in tissues in which fatty acid catabolism is significant, such as the liver, heart, and skeletal muscle (Jalouli et al., 2003; Lee et al., 2003; Schiffrin et al., 2003). Subtype PPAR $\gamma$ is highly expressed in adipose tissue, where it regulates adipocyte differentiation, lipid storage, and insulin sensitivity (Chawla et al., 2003; Schiffrin et al., 2003). Much less is known about the function of $\operatorname{PPAR} \delta$, although it is highly expressed in the brain, colon, and skin (Braissant and Wahli, 1998; Matsuura et al., 1999; Mano et al., 2000). In mice, PPAR $\delta$ deficiency leads to placental defects and results in frequent midgestational lethality (Barak et al., 2002), suggesting that this nuclear recep- 
tor may play an important role in the control of reproductive processes in mammalian species.

Administration of recombinant bST to dairy cows has become a common management practice in the United States for enhancing milk production (Peel and Bauman, 1987). However, this practice has raised numerous concerns, as exogenous bST initially was shown to decrease fertility in dairy cattle (Cole et al., 1992; Zhao et al., 1992). It was suggested that the negative effect of supplemental bST on fertility might be caused, in part, by lower estrous detection rates (Kirby et al., 1997; Lefebvre and Block, 1992). Recent studies indicated that exogenous bST increased pregnancy rates in lactating dairy cows when administered at estrus in repeat breeding cows (Morales-Roura et al., 2001) or when combined with a regimen for synchronization of ovulation and timed AI (Moreira et al., 2000, 2001). This raises the possibility that bST administration to dairy cows during the peri-ovulatory period may have a positive effect on the endocrine and biochemical signals between the conceptus and maternal uterus at the time of pregnancy establishment.

Given the lack of information relating uterine components of the PGF cascade and supplemental bST, the objective of this study was to examine the effect of exogenous bST on uterine endometrial expression of ER $\alpha$, PGHS-2, and PPAR $\delta$ in lactating Holstein cows, and to determine whether those responses vary with stage of the estrous cycle.

\section{MATERIALS AND METHODS}

\section{Experimental Design}

Twenty-one multiparous Holstein cows (average $\mathrm{DIM}=80$ ) were used in a completely randomized design to examine the effect of exogenous bST on uterine endometrial expression of $\mathrm{ER} \alpha$, PGHS-2, and PPAR $\delta$ during the estrous cycle. Detailed cow management and experimental manipulations were described previously (Pershing et al., 2002). Briefly, lactating Holstein cows were milked 3 times daily and fed a TMR that contained 1.65 $\mathrm{Mcal} / \mathrm{kg}$ and $18.1 \% \mathrm{CP}$ (DM basis) during the entire experiment (March to May 2000). At approximately 44 DIM, cows were presynchronized with an injection of GnRH (Cystorelin, Merial Ltd., Iselin, NJ; 100 mg, i.m.) followed $7 \mathrm{~d}$ later with $\mathrm{PGF}_{2 \alpha}$ (Lutalyse, Pharmacia Animal Health, Kalamazoo, MI; 25 mg, i.m.). Twelve days after the $\mathrm{PGF}_{2 \alpha}$ injection, the Ovsynch program was initiated with an i.m. injection of GnRH (100 mg) followed $7 \mathrm{~d}$ later with $\mathrm{PGF}_{2 \alpha}(25 \mathrm{mg})$. Forty-eight hours after the administration of $\mathrm{PGF}_{2 \alpha}$, cows received a second dose of $\mathrm{GnRH}$ to induce ovulation. On the day of expected ovulation (approximately $16 \mathrm{~h}$ after the second GnRH administration), cows were assigned randomly to serve as untreated controls $(n=10)$ or to receive an i.m. injection of bST (Posilac, Monsanto Co., St. Louis, MO; $500 \mathrm{mg}$ ). Within each treatment, cows that ovulated ( $\mathrm{n}=9 \mathrm{bST}, 8$ control) were killed on either $\mathrm{d} 3$ or 7 following initiation of bST treatment. Ovulation was verified by ultrasonography within $48 \mathrm{~h}$ of the second $\mathrm{GnRH}$ dose and later confirmed at slaughter.

\section{RNA Isolation and Analysis}

Reproductive tracts were collected and brought to the laboratory within $15 \mathrm{~min}$ of slaughter. Uterine horns ipsilateral to the corpus luteum were trimmed free of the broad ligament, and samples ( $\sim 5 \mathrm{~g})$ of intercaruncular endometrial tissue were collected and immediately frozen at $-80^{\circ} \mathrm{C}$ for subsequent RNA and Western blot analyses. Total cellular RNA was isolated from endometrial tissues using TriZol reagent (Life Technologies, Grand Island, NY) following the manufacturer's instructions. Samples of RNA ( $20 \mu \mathrm{g} / \mathrm{lane})$ were fractionated in a $1 \%(\mathrm{wt} / \mathrm{vol})$ agarose-formaldehyde gel, blotted to Biotrans nylon membranes (ICN, Irvine, CA), and prehybridized in Rapid-Hyb buffer (Amersham Pharmacia Biotech, Piscataway, NJ) at $60^{\circ} \mathrm{C}$ for $1 \mathrm{~h}$. The filters then were hybridized for $2 \mathrm{~h}$ at $60^{\circ} \mathrm{C}$ in RapidHyb buffer with ${ }^{32}$ P-labeled ER $\alpha$ (Ing et al., 1996), bovine PGHS-2 (a gift from Jean Sirois, Universite de Montreal, St-Hyacinthe, Canada), and bovine PPAR $\delta$ (amplified by reverse transcription-PCR from bovine endometrial RNA) cDNA probes. The cDNA probe for $\operatorname{PPAR} \delta$ was generated using a set of primers (forward: 5'-CACTCTCACTGCTGGACAA-3'; reverse: 5'-TGCG GTTCTTCTTCTGGATT-3') designed from the bovine PPAR $\delta$ sequence (GenBank accession number: AF229357). The size (216 bp) and identity of the PCR product were further verified by DNA sequencing before its use in Northern blot analyses. The membranes were washed sequentially in $2 \times$ saline sodium citrate/ $0.1 \%$ (wt/vol) SDS at room temperature for $20 \mathrm{~min}$ and $0.1 \times$ saline sodium citrate $/ 0.1 \%$ (wt/vol) SDS at $50^{\circ} \mathrm{C}$ for 15 min. Hybridization signals were detected by exposing membranes to x-ray film (X-Omat Blue XB 1, Eastman Kodak Co., Rochester, NY) at $-80^{\circ} \mathrm{C}$ for 24 to $48 \mathrm{~h}$. Hybridization signals for each target gene were quantified by densitometric scanning (Kodak Electrophoresis Documentation and Analysis System 290, Eastman Kodak Co.). Following autoradiography, the membranes were stripped with $1 \%$ (wt/vol) SDS and rehybridized with $18 \mathrm{~S}$ ribosomal RNA probe to verify the consistency of RNA loading and specificity of treatment effect.

\section{Western Blot Analysis}

The abundance of $\mathrm{ER} \alpha$, PGHS-2, and PPAR $\delta$ in uterine endometrium was examined by Western blot analy- 


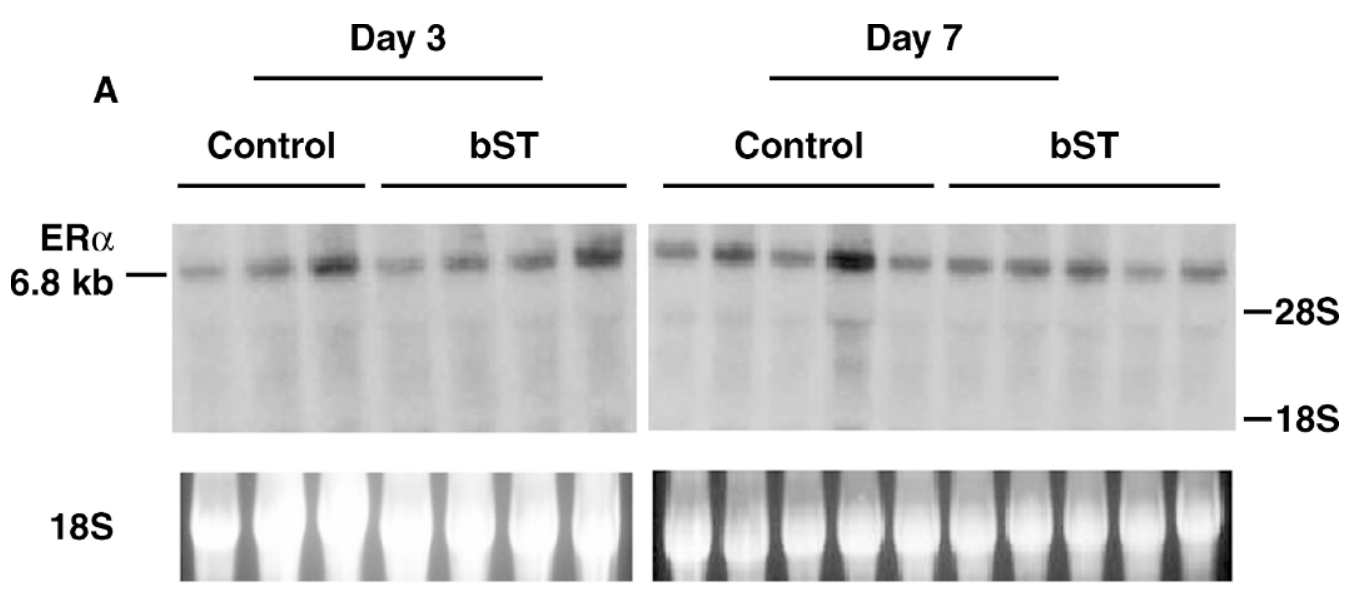

B

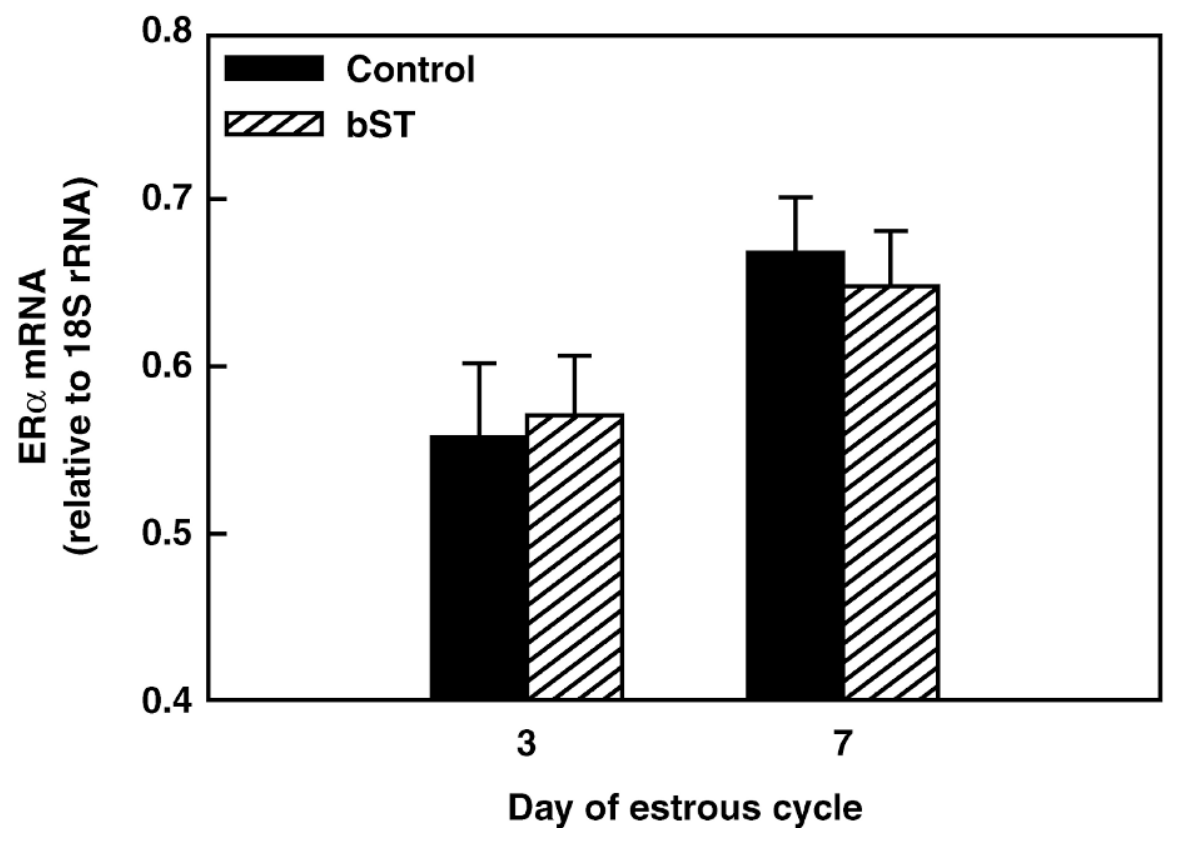

Figure 1. Effects of bST on uterine endometrial expression of estrogen receptor $\alpha$ (ER $\alpha$ ) mRNA in control (d 3, lanes 1 to 3; d 7, lanes 1 to 5 ) and bST-treated (d 3, lanes 4 to 7; d 7, lanes 6 to 10) cows. Each lane represents a different cow. Day of estrous cycle differed, $P=0.02$.

sis. Total protein was extracted from intercaruncular endometrial tissues ( 300 to $400 \mathrm{mg}$ ) by tissue homogenization in ice-cold lysis buffer [50 $\mathrm{m} M$ Tris- $\mathrm{HCl}, \mathrm{pH} 7.5$, $300 \mathrm{~m} M \mathrm{NaCl}, 2 \mathrm{~m} M$ EDTA, $2 \mathrm{~m} M$ ethylene glycol-bis (2-aminoethyl ether)-N,N, $\mathrm{N}^{\prime}, \mathrm{N}^{\prime}$-tetraacetic acid (EGTA), $50 \mathrm{~m} M \mathrm{NaF}, 1 \%$ (wt/vol) Nonidet P-40, $20 \mathrm{mM}$ b-glycerophosphate, $2 \mathrm{mM} \mathrm{Na} \mathrm{VO}_{4}, 10 \%$ (wt/vol) glycerol, $1 \mathrm{~m} M$ phenylmethylsulfonyl fluoride, and $10 \mathrm{~g} / \mathrm{mL}$ each of aprotinin, leupeptin, and pepstatin; Binelli et al., 2000]. Protein concentrations in cell lysates were determined by the Bradford method (Bradford, 1976), with BSA used as the standard. For each endometrial sample, $100 \mu \mathrm{g}$ of protein was subjected to $7.5 \%$ (wt/ vol) SDS-PAGE in the presence of $\beta$-mercaptoethanol followed by electrotransfer onto a nitrocellulose membrane (Hybond ECL, Amersham Pharmacia Biotech) at $4^{\circ} \mathrm{C}$ overnight. Following electrotransfer, the membranes were transiently stained with Ponceau S solution (Sigma Chemical Co., St. Louis MO) to determine the efficiency of protein transfer. The membranes were blocked in Tris-buffered saline (TBS) containing 5\% (wt/vol) Carnation instant nonfat dry milk for $2 \mathrm{~h}$ at 
A

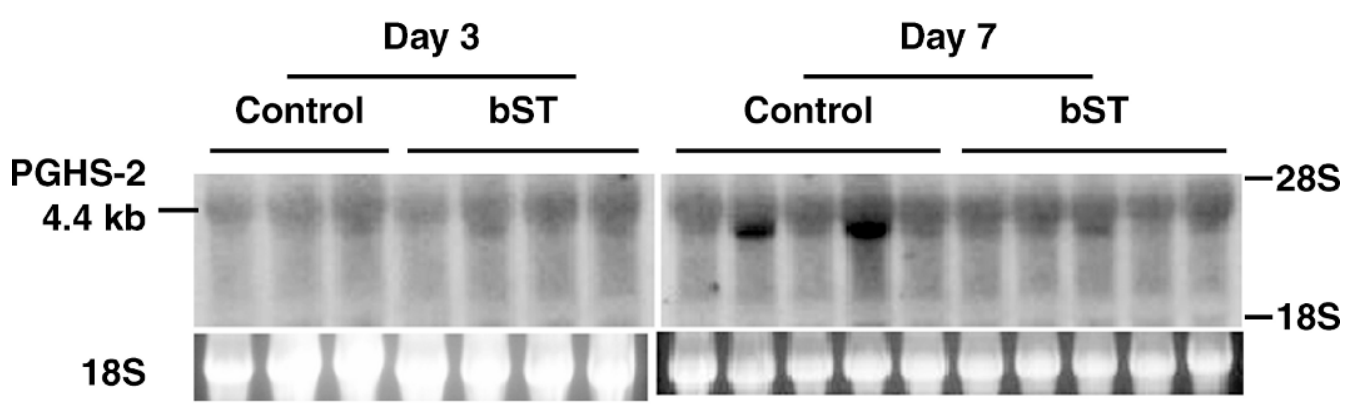

B

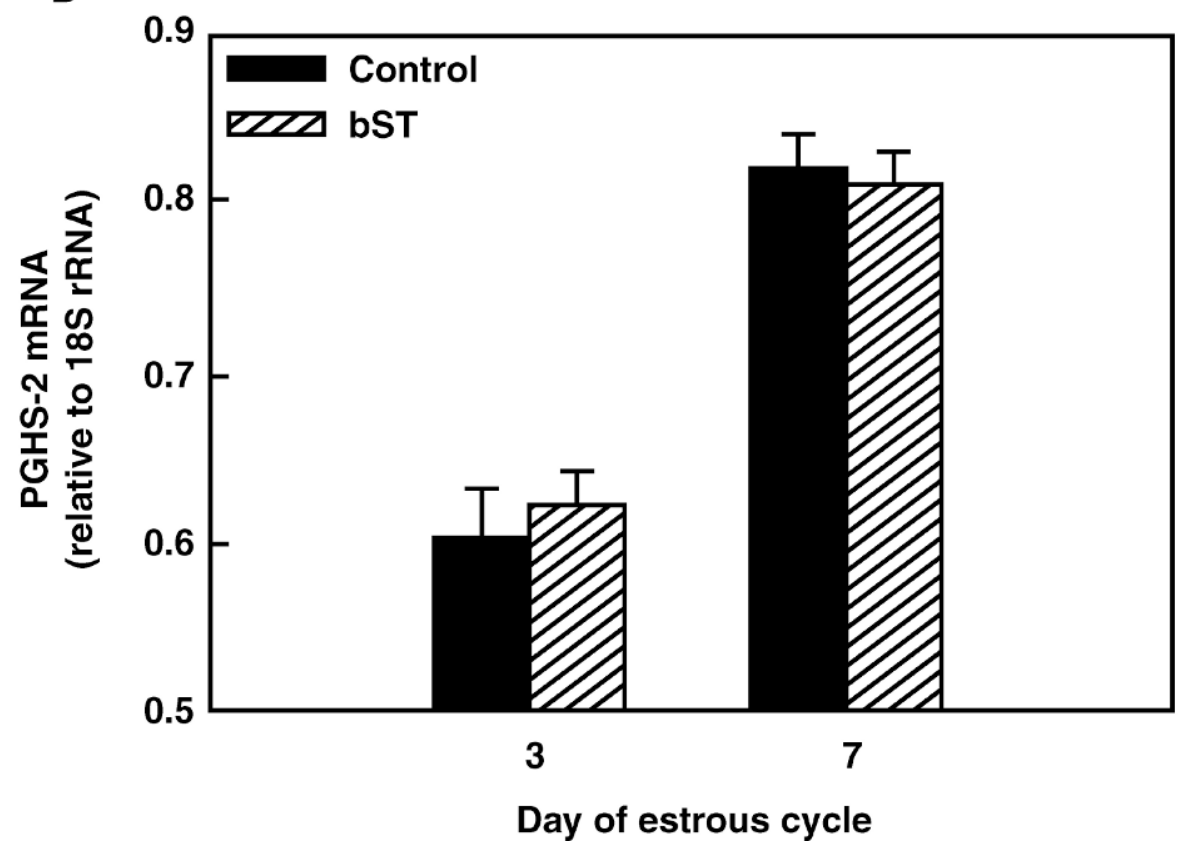

Figure 2. Effects of bST on uterine endometrial expression of prostaglandin endoperoxide synthase-2 (PGHS-2) mRNA in control (d 3, lanes 1 to 3; d 7, lanes 1 to 5) and bST-treated (d 3, lanes 4 to 7; d 7, lanes 6 to 10) cows. Each lane represents a different cow. Day of estrous cycle differed, $P<0.01$.

room temperature. The membranes were then incubated with $200 \mu \mathrm{g} / \mathrm{mL}$ of primary antibodies against $\mathrm{ER} \alpha$ (mouse monoclonal anti-ER $\alpha$, Amersham), PGHS2 (rabbit polyclonal anti-PGHS-2, Cayman Chemical Co., Ann Arbor, MI), or PPAR $\delta$ (rabbit polyclonal antiPPAR $\delta$, Santa Cruz Biotechnology Inc., Santa Cruz, CA) in a total volume of $10 \mathrm{~mL}$ of TBS for $2 \mathrm{~h}$ at room temperature. After incubation, the membranes were washed with 3 changes of $0.1 \%$ (wt/vol) Tween-20 TBS for $20 \mathrm{~min}$. The membranes were then incubated with secondary antibodies (antimouse horseradish peroxidase for $\mathrm{ER} \alpha$, Amersham; antirabbit horseradish peroxidase for PGHS-2 and PPAR $\delta$, Cayman), washed with TBS, and blotted dry. The protein bands were visualized by enhanced chemiluminescence following the manufacturer's instructions (Renaissance Western Blot
Chemiluminescence Reagent Plus, NEN Life Science Products, Inc., Boston, MA). The relative abundance of each protein was detected by exposing immunoblots to x-ray film (Super RX, Fuji Photo Film Co., Tokyo, Japan) for 10 to $30 \mathrm{~s}$. Protein signals were quantified by densitometric analysis (Kodak EDAS 290).

\section{Statistical Analyses}

Messenger RNA and protein responses were evaluated by least squares ANOVA using the GLM procedure of the SAS software package (SAS Inst., Inc., Cary, NC). The mathematical model for uterine mRNA and protein responses included treatment, day of estrous cycle, and treatment $\times$ day interaction. For all target genes, the densitometric values were expressed as ratios of target 
A

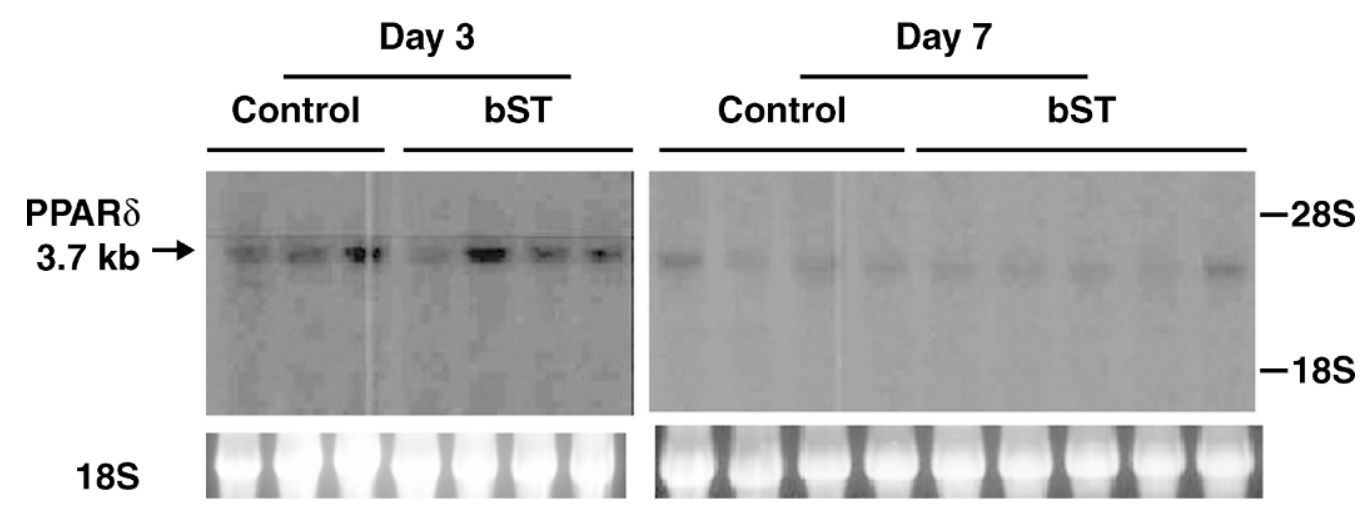

B

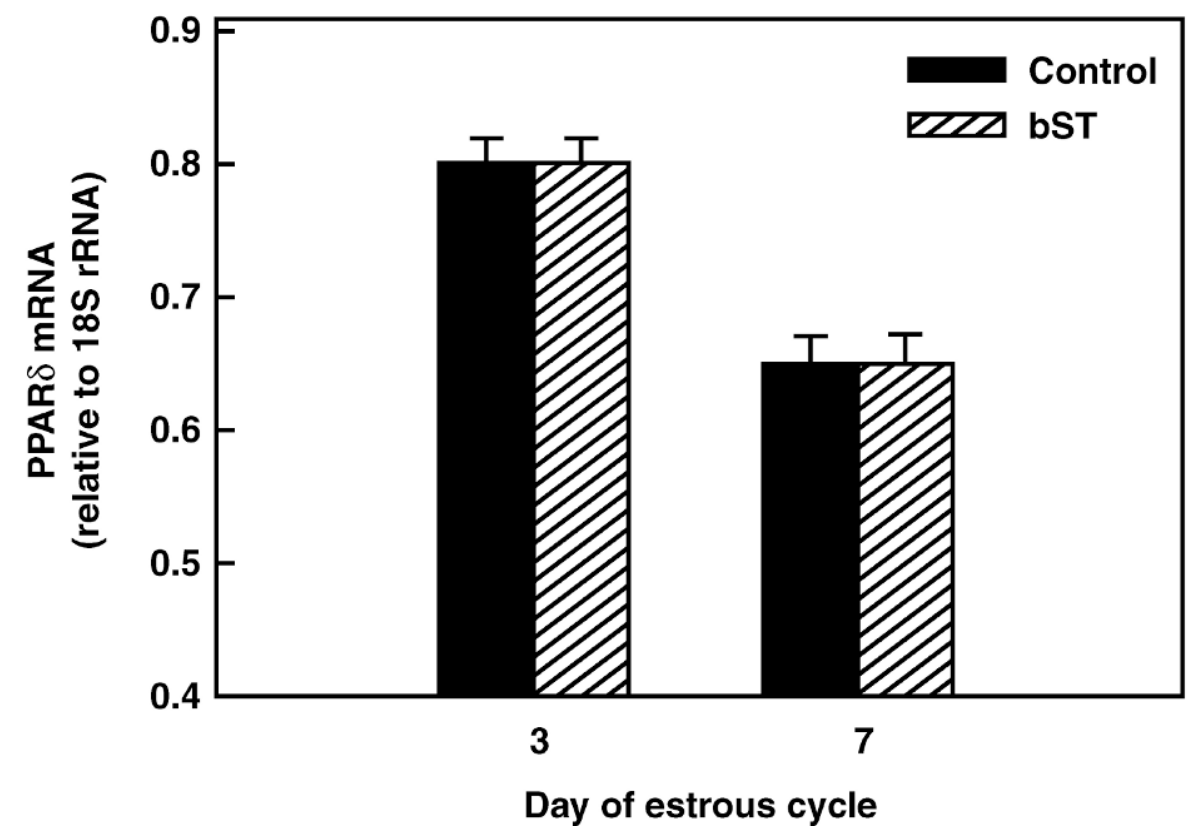

Figure 3. Effects of bST on uterine endometrial expression of peroxisome proliferator-activated receptor $\delta$ (PPAR $\delta$ ) mRNA in control (d 3, lanes 1 to 3; d 7, lanes 1 to 4) and bST-treated (d 3, lanes 4 to 7; d 7, lanes 5 to 9) cows. Each lane represents a different cow. Day of estrous cycle differed, $P<0.01$.

Table 1. Pearson (upper right) and partial ${ }^{1}$ (lower left) correlation coefficients for uterine endometrial estrogen receptor $\alpha(\mathrm{ER} \alpha)$, prostaglandin endoperoxide synthase-2 (PGHS-2), and peroxisome proliferator-activated receptor $\delta(\mathrm{PPAR} \delta)$ mRNA transcripts.

\begin{tabular}{llll}
\hline & ER $\alpha$ & PGHS-2 & PPAR $\delta$ \\
\hline ER $\alpha$ & - & $0.84^{* *}$ & $-0.52^{* *}$ \\
PGHS-2 & $0.87^{* *}$ & - & $-0.81^{* *}$ \\
PPAR $\delta$ & 0.07 & 0.19 & - \\
\hline
\end{tabular}

${ }^{1}$ Partial correlations were adjusted for treatment, day of estrous cycle, and treatment $\times$ day interaction. ${ }^{* *}$ Significant correlation at $P<0.01$.

gene values over the corresponding $18 \mathrm{~S}$ rRNA values. Pearson and partial correlations among endometrial genes and proteins were determined using the CORR and MANOVA procedures, respectively. Partial correlations were adjusted for treatment, day of estrous cycle, and treatment $\times$ day interaction.

\section{RESULTS}

\section{Uterine ER $\alpha$, PGHS-2, and PPAR $\delta$ Genes}

Uterine endometrial mRNA encoding ER $\alpha$, PGHS-2, and $\operatorname{PPAR} \delta$ were readily detectable on $\mathrm{d} 3$ and 7 of the 
A
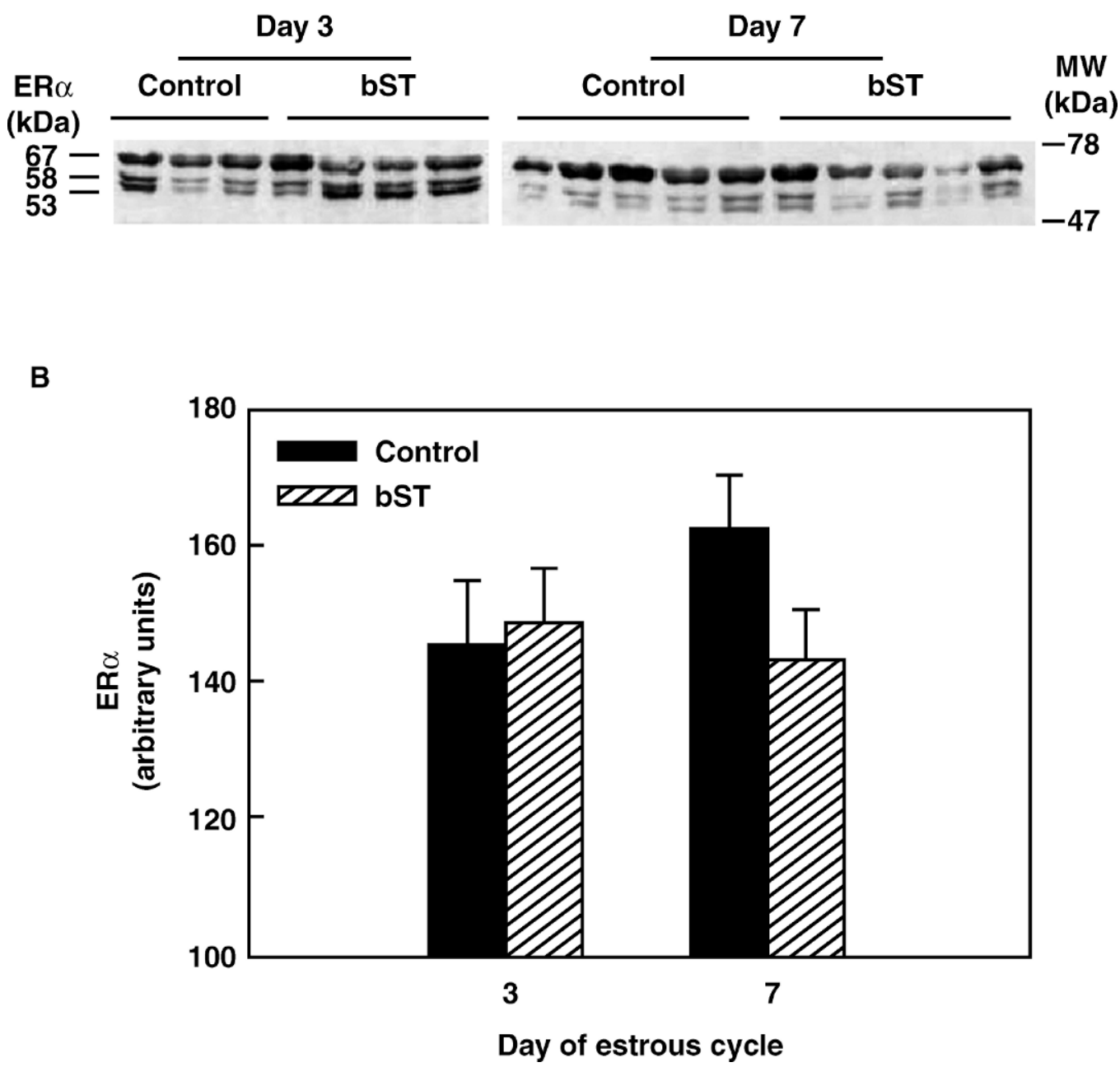

Figure 4. Effects of bST on endometrial concentrations of estrogen receptor $\alpha$ (ER $\alpha$ ) protein in control (d 3, lanes 1 to 3; $d$, lanes 1 to 5) and bST-treated (d 3, lanes 4 to 7; d 7, lanes 6 to 10) cows. Each lane represents a different cow.

estrous cycle in lactating Holstein cows (Figures 1, 2, and 3). Northern blot analyses identified single mRNA transcripts for ER $\alpha$ (6.8 kb; Figure 1A), PGHS-2 (4.4 $\mathrm{kb}$; Figure 2A), and PPAR $\delta(3.7 \mathrm{~kb}$; Figure $3 \mathrm{~A})$ genes. When averaged within treatments and stages of the estrous cycle, concentrations of $\mathrm{ER} \alpha$ and PGHS-2 mRNA transcripts in the endometrium were greater $(P$ $<0.05$ ) on $d 7$ than on $d 3$ of the estrous cycle (Figures $1 \mathrm{~B}$ and $2 \mathrm{~B})$. Conversely, the abundance of endometrial PPAR $\delta$ mRNA transcript decreased $(P<0.01)$ between $\mathrm{d} 3$ and 7 of the estrous cycle (Figure 3B). There were no detectable differences between control and bST-treated cows on either d 3 or $d 7$ of the estrous cycle for all 3 genes (Figures 1, 2, and 3). Pearson and partial correlation analyses revealed a positive relationship $(P<0.01)$ between endometrial ER $\alpha$ and PGHS-2 mRNA concentrations (Table 1). When unadjusted for treatment, stage of the estrous cycle, and among-cow variations, both ER $\alpha$ and PGHS-2 mRNA concentrations were negatively correlated $(P<0.01)$ with that of PPAR $\delta$ mRNA (Table 1). However, the apparent negative relationships between PPAR $\delta$ and either ER $\alpha$ or PGHS- 2 mRNA were no longer detectable when mRNA responses were adjusted for treatment and stage of the estrous cycle (Table 1).

\section{Uterine ER $\alpha$, PGHS-2, and PPAR $\delta$ Proteins}

Western immunoblotting revealed 3 isoforms for ER $\alpha$ protein (MW $=53$ to $67 \mathrm{kDa}$; Figure 4A), a doublet for PGHS-2 protein (MW = 70 to $72 \mathrm{kDa}$; Figure 5A), and 4 isoforms for PPAR $\delta$ protein $(\mathrm{MW}=47$ to $67 \mathrm{kDa}$; Figure 6A). Results for the ER $\alpha$ protein are consistent with a previous report, which identified 3 to 4 isoforms 
A
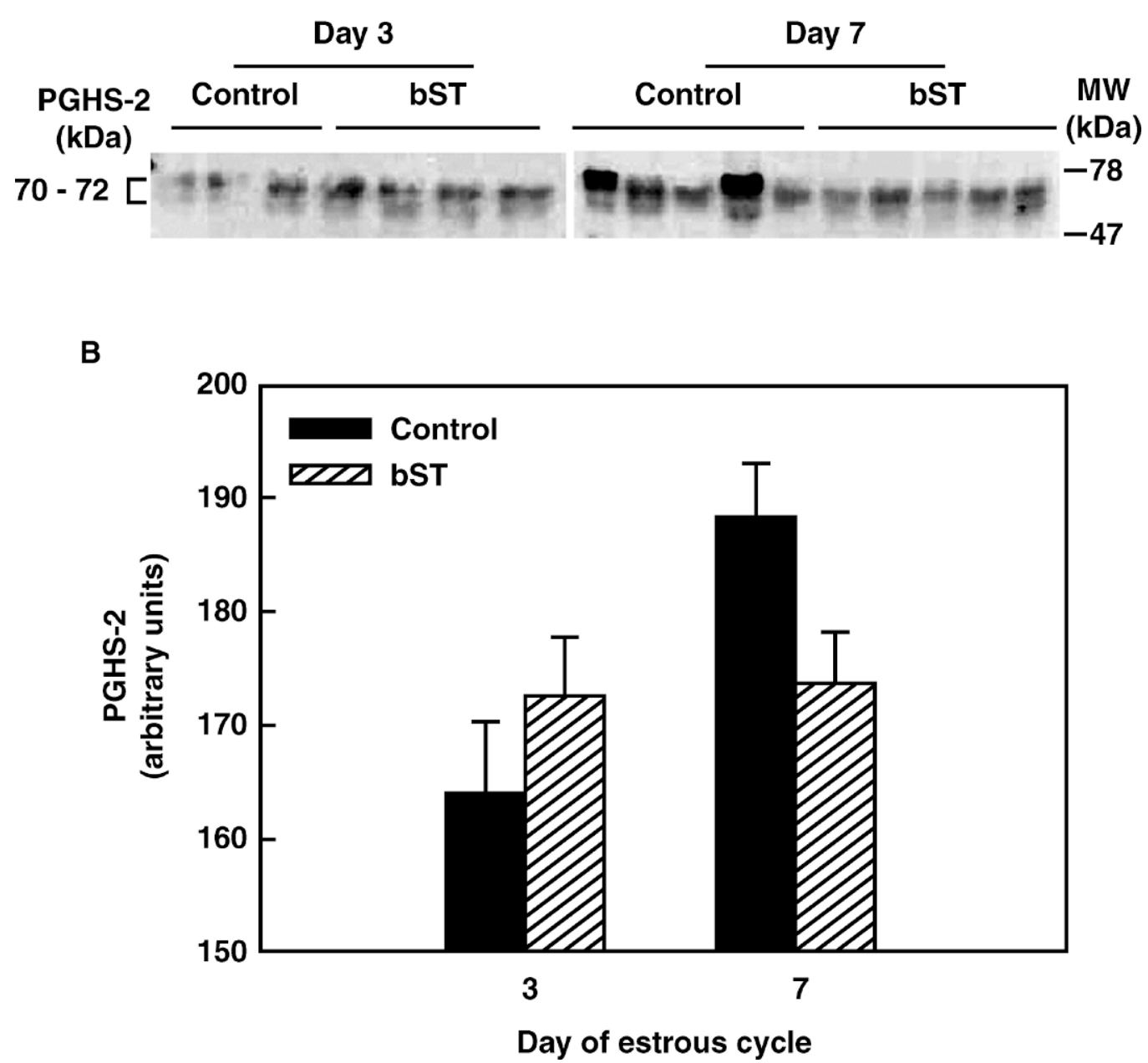

Figure 5. Effects of bST on endometrial concentrations of prostaglandin endoperoxide synthase-2 (PGHS-2) protein in control (d 3, lanes 1 to $3 ; \mathrm{d} 7$, lanes 1 to 5 ) and bST-treated (d 3, lanes 4 to 7 ; d 7, lanes 6 to 10) cows. Each lane represents a different cow. Treatment $\times$ day interaction, $P<0.05$.

of rat pituitary ER $\alpha$ protein when probed with an antiER $\alpha$ polyclonal antibody (Pasqualini et al., 1999). The doublet detected for immunoreactive PGHS-2 protein is also consistent with the literature data on cyclooxygenase-2, which tends to resolve as a doublet on Western immunoblots (Habib et al., 1993; Crew et al., 2000). Western blot analysis revealed multiple bands for the PPAR $\delta$ protein (Figure 6A). The anti-PPAR $\delta$ polyclonal antibody (H-74) used in this study reacts with PPAR $\delta$ of mouse, rat, and human origin but does not crossreact with PPAR $\alpha$ or PPAR $\gamma$. Thus, the multiple bands detected for the PPAR $\delta$ protein in the current study may represent distinct isoforms of PPAR $\delta$ in bovine uterine endometrial tissue.

When averaged within treatments and stages of the estrous cycle, the concentration of the full length $\mathrm{ER} \alpha$ protein $(67 \mathrm{kDa})$ was unaffected by bST or day of the estrous cycle (Figure 4B). A treatment $\times$ day interaction was detected $(P<0.05)$ for endometrial PGHS-2 protein abundance. Compared with control cows, bST decreased endometrial PGHS-2 concentration at $d 7$ of the estrous cycle (Figure 5B). When pooled together, the abundance of PPAR $\delta$ isoforms did not differ between control and bST-treated cows (Figure 6B). There were no apparent relationships among $\mathrm{ER} \alpha$, PGHS-2, and PPAR $\delta$ protein concentrations in the endometrium of cyclic Holstein cows (Table 2).

\section{DISCUSSION}

The observation that bST receptors are expressed in several reproductive tissues (Kirby et al., 1996) raises the possibility that bST may play a direct role in the control of mammalian reproductive function. In the 
A

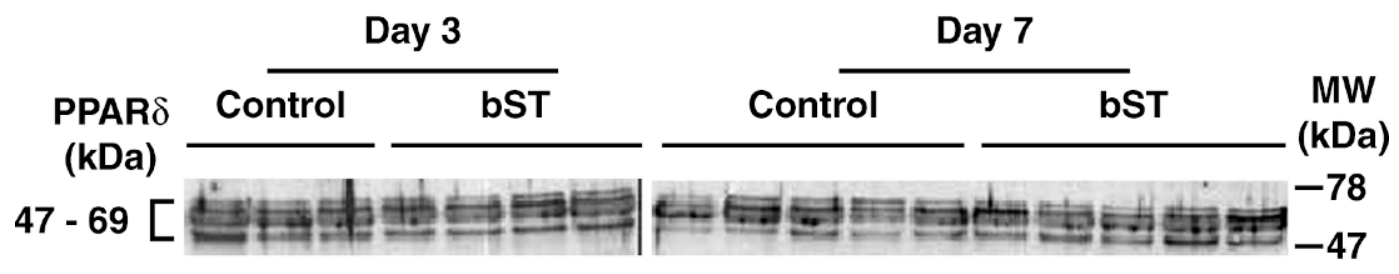

B

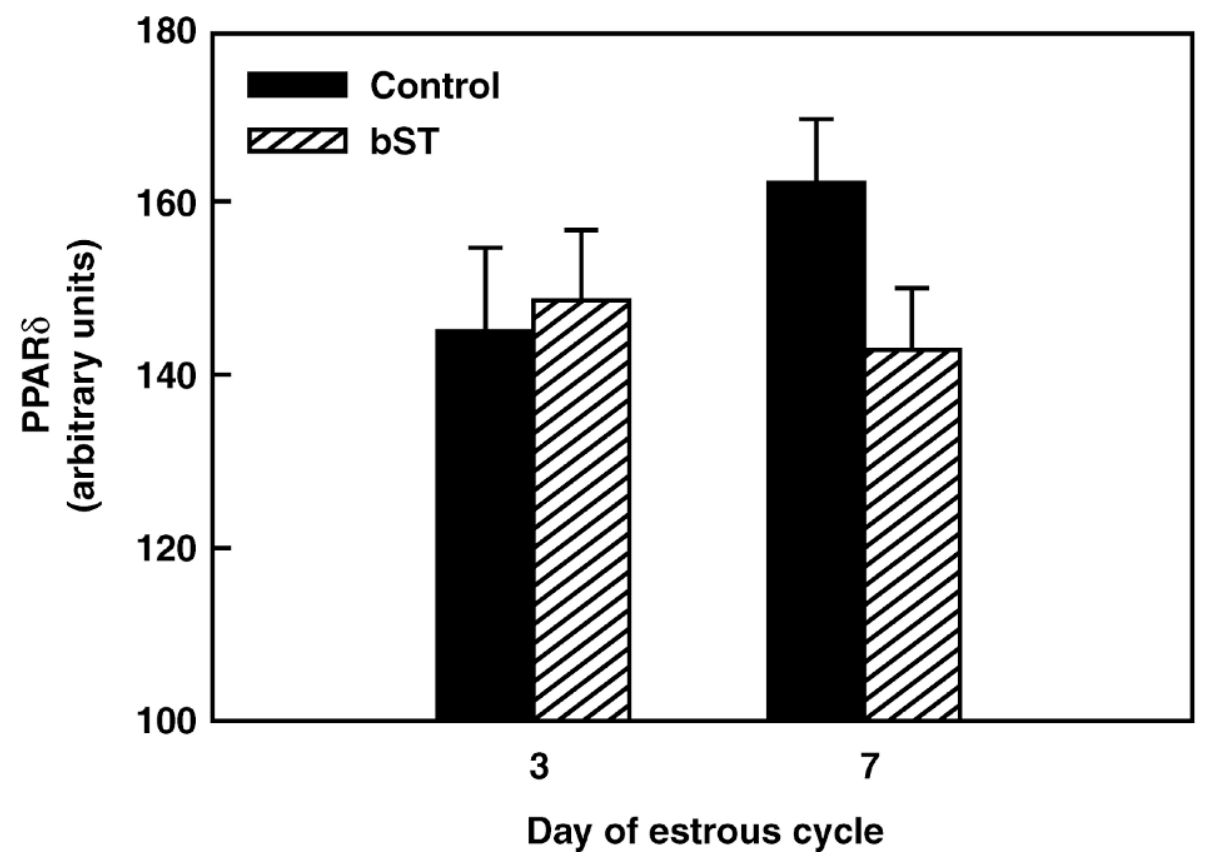

Figure 6. Effects of bST on endometrial concentrations of peroxisome proliferator-activated receptor $\delta(\operatorname{PPAR} \delta)$ protein in control (d 3, lanes 1 to $3 ; \mathrm{d}$ 7, lanes 1 to 5) and bST-treated (d 3, lanes 4 to 7; d 7, lanes 6 to 10) cows. Each lane represents a different cow.

present study, uterine endometrial ER $\alpha$ and PGHS-2 mRNA concentrations were greater on $\mathrm{d} 7$ than on $\mathrm{d} 3$ of the estrous cycle, but did not differ between control

Table 2. Pearson (upper right) and partial ${ }^{1}$ (lower left) correlation coefficients for uterine endometrial estrogen receptor $\alpha$ (ER $\alpha$ ), prostaglandin endoperoxide synthase-2 (PGHS-2), and peroxisome proliferator-activated receptor $\delta(\operatorname{PPAR} \delta)$ proteins.

\begin{tabular}{llll}
\hline & ER $\alpha$ & PGHS-2 & PPAR $\delta$ \\
\hline ER $\alpha$ & - & 0.01 & 0.16 \\
PGHS-2 & -0.46 & - & 0.18 \\
PPAR $\delta$ & 0.26 & -0.34 & - \\
\hline
\end{tabular}

${ }^{1}$ Partial correlations were adjusted for treatment, day of estrous cycle, and treatment $\times$ day interaction. None of the correlations were significant. and bST-treated cows. These findings are consistent with a previous report that detected no growth hormone effects on uterine endometrial $\mathrm{ER} \alpha$ gene expression in ovariectomized ewes receiving ovarian steroid replacement therapy (Spencer et al., 1999). The lack of growth hormone effect on PGHS-2 agrees with a previous in vitro study which detected no growth hormone effects on steady-state PGHS-2 mRNA concentration in cultured bovine endometrial cells (Badinga et al., 2002). In contrast with our findings, Guzeloglu et al. (2004) detected a stimulatory effect of bST on endometrial ER $\alpha$ and PGHS-2 synthesis at $d 17$ of the estrous cycle in nonlactating Holstein cows. These observations collectively suggest that the net effect of supplemental growth hormone on endometrial ER $\alpha$ and PGHS-2 syn- 
thesis may vary depending on the physiological state of the experimental animal (i.e., lactation, stage of estrous cycle, and pregnancy).

Uterine $\mathrm{ER} \alpha$ is known to be up regulated by estradiol (Wu et al., 1996; Ing and Tornesi, 1997; Ing and Ott, 1999) and is generally maximally expressed at estrus in the bovine uterus (Meikle et al., 2001). In the cow, peripheral estradiol exhibits 1 or 2 secondary peaks coinciding with the emergence of 1 or 2 nonovulatory dominant follicles during the interestrous interval (Savio et al., 1988; Sirois and Fortune, 1988; Badinga et al., 1992). It is conceivable that the greater $\mathrm{ER} \alpha$ and PGHS-2 mRNA concentrations detected in the bovine endometrium at $d 7$ of the estrous cycle may reflect the subtle rise in plasma $\mathrm{E}_{2}$ that originates from the dominant follicle of the first follicular wave (Badinga et al., 1992). Alternatively, the previously documented inhibitory effects of progesterone on expression of $\mathrm{ER} \alpha$ mRNA (Spencer et al., 1996; Wu et al., 1996; McDowell et al., 1999) may occur at later stages of the luteal phase that were not examined in the current study.

Peroxisome proliferator-activated receptors are ligand-activated transcription factors that regulate multiple physiological processes, including reproduction, development, and energy metabolism (Chinetti et al., 2000; Panadero et al., 2000; Barak et al., 2002). Tissue distributions of $\operatorname{PPAR} \alpha$ and $\operatorname{PPAR} \gamma$ gene transcripts indicate that they play roles in fatty acid catabolism (Jalouli et al., 2003; Lee et al., 2003) and adipogenesis (Chawla et al., 2003; Schiffrin et al., 2003), respectively. Much less is known about the function and regulation of $\operatorname{PPAR} \delta$, although it is highly expressed in the brain, colon, and skin (Braissant and Wahli, 1998; Matsuura et al., 1999; Mano et al., 2000). In the present study, concentrations of endometrial $\operatorname{PPAR} \delta$ mRNA were greater in d-3 than in d-7 cyclic endometrium of Holstein cows. There was an inverse relationship between endometrial PPAR $\delta$ mRNA concentration and that of $\mathrm{ER} \alpha$ and PGHS-2 within the first week of the estrous cycle. The physiological relevance of the inverse relationships between expression of $\mathrm{PPAR} \delta$ and that of $\mathrm{ER} \alpha$ or PGHS-2 genes in the bovine uterus is unknown and warrants further investigation. The present study would indicate that the negative correlation between $\operatorname{PPAR} \delta$ and ER $\alpha$ and PGHS-2 gene expression may be specific to stage of the estrous cycle because the negative relationships no longer existed after adjustment of the mathematical models for stage of the estrous cycle. Conversely, positive Pearson and partial correlations between concentrations of ER $\alpha$ and PGHS-2 mRNA further support the concept that $\mathrm{ER} \alpha$ may be a necessary physiological mediator of uterine $\mathrm{PGF}_{2 \alpha}$ biosynthesis in domestic ruminants.

\section{CONCLUSION}

Results provide a direct evidence for $\operatorname{PPAR} \delta$ gene expression in the bovine uterus. Endometrial PPAR $\delta$ mRNA concentration decreased, whereas that of ER $\alpha$ and PGHS-2 increased between $d 3$ and 7 of the estrous cycle. Negative correlations between the PPAR $\delta$ gene and both ER $\alpha$ and PGHS-2 genes were apparently dependent on stage of the estrous cycle because the inverse relationships no longer existed when the mathematical models were adjusted for stage of the estrous cycle. Positive Pearson and partial correlations were detected between endometrial ER $\alpha$ and PGHS-2 mRNA concentrations, further supporting the concept that $\mathrm{ER} \alpha$ may be the necessary physiological mediator of endometrial $\mathrm{PGF}_{2 \alpha}$ biosynthesis in cattle. The apparent lack of bST effect on expression of PGHS-2 was in contrast to a recent report in nonlactating Holstein cows (Guzeloglu et al., 2004), and would suggest that the net effect of supplemental bST on uterine ER $\alpha$ and PGHS2 synthesis varies depending on the physiological state of the experimental animal.

\section{REFERENCES}

Badinga, L., M. A. Driancourt, J. D. Savio, D. Wolfenson, M. Drost, R. L. de la Sota, and W. W. Thatcher. 1992. Endocrine and ovarian responses associated with the first-wave dominant follicle in cattle. Biol. Reprod. 47:871-883.

Badinga, L., A. Guzeloglu, and W. W. Thatcher. 2002. Bovine somatotropin attenuates phorbol ester-induced prostaglandin $\mathrm{F}_{2 \alpha}$ production in bovine endometrial cells. J. Dairy Sci. 85:537-543.

Barak, Y., D. Liao, W. He, E. S. Ong, M. C. Nelson, J. M. Olefsky, R. Boland, and R. M. Evans. 2002. Effects of peroxisome proliferatoractivated receptor $\delta$ on placentation, adiposity, and colorectal cancer. Proc. Natl. Acad. Sci. USA 99:303-308.

Beard, A. P., and G. E. Lamming. 1994. Oestradiol concentration and the development of uterine oxytocin receptors and oxytocininduced PGF2 alpha release in ewes. J. Reprod. Fertil. 100:469-475.

Binelli, M., A. Guzeloglu, L. Badinga, D. R. Arnold, J. Sirois, T. R. Hansen, and W. W. Thatcher. 2000. Interferon- $\tau$ modulates phorbol ester-induced production of prostaglandin and expression of cyclooxygenase-2 and phospholipase-A2 from bovine endometrial cells. Biol. Reprod. 63:417-424.

Bradford, M. M. 1976. A rapid and sensitive method for quantitation of microgram quantities of protein utilizing the principle of protein-dye binding. Anal. Biochem. 72:248-254.

Braissant, O., and W. Wahli. 1998. Differential expression of peroxisome proliferator-activated receptor- $\alpha,-\beta$, and $-\gamma$ during rat embryonic development. Endocrinology 139:2748-2754.

Chawla, A., C.-H. Lee, Y. Barak, W. He, J. Rosenfeld, D. Liao, J. Han, H. Kang, and R. M. Evans. 2003. PPAR $\delta$ is a low-density lipoprotein sensor in macrophages. Proc. Natl. Acad. Sci. USA 100:1268-1273.

Chinetti, G., J.-C. Fruchart, and B. Staels. 2000. Peroxisome proliferator-activated receptors (PPARs): Nuclear receptors at the crossroads between lipid metabolism and inflammation. Inflamm. Res. 49:497-505.

Cole, W. J., P. J. Eppard, B. C. Boysen, K. S. Madsen, R. H. Sorbet, M. A. Miller, R. L. Hintz, T. C. White, W. E. Ribellin, B. G. Hammond, R. J. Collier, and G. M. Lanza. 1992. Response of dairy cows to high doses of a sustained bovine somatotropin administered during two lactations. 2. Health and reproduction. J. Dairy Sci. 75:111-123. 
Crew, T. E., D. J. E. Elder, and C. Paraskeva. 2000. A cyclooxygenase2 (COX-2) selective non-steroidal anti-inflammatory drug enhances the growth inhibitory effect of butyrate in colorectal carcinoma cells expressing COX-2 protein: Regulation of COX-2 by butyrate. Carcinogenesis 21:69-77.

Guzeloglu, A., T. R. Bilby, A. Meikle, S. Kamimura, A. Kowalski, F. Michel, L. A. MacLaren, and W. W. Thatcher. 2004. Pregnancy and bovine somatotropin in nonlactating dairy cows: II. Endometrial gene expression related to maintenance of pregnancy. J. Dairy Sci. 87:3268-3279.

Habib, A., C. Creminon, Y. Frobert, J. Grassi, P. Pradelles, and J. Maclouf. 1993. Demonstration of an inducible cyclooxygenase in human endothelial cells using antibodies raised against the carboxyl-terminal region of the cyclooxygenase-2. J. Biol. Chem. 268:23448-23454.

Ing, N. H., and T. L. Ott. 1999. Estradiol up-regulates estrogen receptor- $\alpha$ messenger ribonucleic acid in sheep endometrium by increasing its stability. Biol. Reprod. 60:134-139.

Ing, N. H., T. E. Spencer, and F. W. Bazar. 1996. Estrogen enhances endometrial estrogen receptor gene expression by a posttranscriptional mechanism in the ovariectomized ewe. Biol. Reprod. 54. $591-599$.

Ing, N. H., and M. B. Tornesi. 1997. Estradiol up-regulates estrogen receptor and progesterone receptor gene expression in specific ovine uterine cells. Biol. Reprod. 56:1205-1215.

Irvine, R. F. 1982. How is the level of free arachidonic acid controlled in mammalian cells? Biochem. J. 204:3-16.

Jalouli, M., L. Carlsson, C. Ameen, D. Linden, A. Ljungberg, L. Michalik, S. Eden, W. Wahli, and J. Oscarsson. 2003. Sex difference in hepatic peroxisome proliferator-activated receptor a expression: Influence of pituitary and gonadal hormones. Endocrinology 144:101-109.

Kim, S., Y. Choi, T. E. Spencer, and F. W. Bazer. 2003. Effects of the estrous cycle, pregnancy and interferon tau on expression of cyclooxygenase two (COX-2) in ovine endometrium. Reprod. Biol. Endocrinol. 1:58-66.

Kirby, C. J., W. W. Thatcher, R. J. Collier, F. A. Simmen, and M. C. Lucy. 1996. Effects of growth hormone and pregnancy on expression of growth hormone receptor, insulin-like growth factor-I, and insulin-like growth factor binding protein-2 and -3 genes in bovine uterus, ovary, and oviduct. Biol. Reprod. 55:996-1002.

Kirby, C. J., S. J. Wilson, and M. C. Lucy. 1997. Response of dairy cows treated with bovine somatotropin to a luteolytic dose of prostaglandin $\mathrm{F}_{2 \alpha}$. J. Dairy Sci. 80:286-294.

Lee, C.-H., P. Olson, and R. M. Evans. 2003. Minireview: Lipid metabolism, metabolic diseases, and peroxisome proliferator-activated receptors. Endocrinology 144:2201-2207.

Lefebvre, D. M., and E. Block. 1992. Effect of recombinant bovine somatotropin on estradiol-induced estrous behavior in ovariectomized heifers. J. Dairy Sci. 75:1461-1464.

Mano, H., C. Kimura, Y. Fujisawa, T. Kameda, M. Watanabe-Mano, H. Kaneko, T. Kaneda, Y. Hakeda, and M. Kumegawa. 2000. Cloning and function of rabbit peroxisome proliferator-activated receptor $\delta / \beta$ in mature osteoclasts. J. Biol. Chem. 275:8126-8132.

Matsuura, H., H. Adachi, R. C. Smart, X. Xu, J. Arata, and A. M. Jetten. 1999. Correlation between expression of peroxisome proliferator-activated receptor beta and squamous differentiation in epidermal and tracheobronchial epithelial cells. Mol. Cell. Endocrinol. 147:85-92.

McCracken, J. A., J. C. Carlson, M. E. Glew, J. R. Goding, D. T. Baird, K. Green, and B. Samuelsson. 1972. Prostaglandin $\mathrm{F}_{2 \alpha}$ identified as a luteolytic hormone in sheep. Nat. New Biol. 238:129-134.

McDowell, K. J., M. H. Adams, C. Y. Adam, and K. S. Simpson. 1999. Changes in equine endometrial oestrogen receptor alpha and progesterone receptor mRNAs during the oestrous cycle, early pregnancy and after treatment with exogenous steroids. J. Reprod. Fertil. 117:135-142.
Meikle, A., L. Sahlin, A. Ferraris, B. Masironi, J. E. Blanc, M. Rodriguez-Irazoqui, M. Rodriguez-Pinon, H. Kindahl, and M. Forsberg. 2001. Endometrial mRNA expression of oestrogen receptor $\alpha$, progesterone receptor and insulin-like growth factor-I (IGF-I) throughout the bovine oestrous cycle. Anim. Reprod. Sci. 68:45-56.

Morales-Roura, J. S., L. Zarco, J. Hernandez-Ceron, and G. Rodriguez. 2001. Effect of short-term treatment with bovine somatotropin at estrus on conception rate and luteal function of repeatbreeding dairy cows. Theriogenology 55:1831-1841.

Moreira, F., C. Orlando, C. A. Risco, R. Mattos, F. Lopes, and W. W. Thatcher. 2001. Effects of presynchronization and bovine somatotropin on pregnancy rates to a timed artificial insemination protocol in lactating dairy cows. J. Dairy Sci. 84:1646-1659.

Moreira, F., C. A. Risco, M. F. A. Pires, J. D. Ambrose, M. Drost, and W. W. Thatcher. 2000. Use of bovine somatotropin in lactating dairy cows receiving timed artificial insemination. J. Dairy Sci. 83:1237-1247.

Panadero, M., E. Herrera, and C. Bocos. 2000. Peroxisome proliferator-activated receptor- $\alpha$ expression in rat liver during postnatal development. Biochimie 82:723-726.

Pasqualini, C., D. Guivarch, Y. V. Boxberg, F. Nothias, J.-D. Vincent, and P. Vernier. 1999. Stage- and region-specific expression of estrogen receptor $\alpha$ isoforms during ontogeny of the pituitary gland. Endocrinology 140:2781-2789.

Peel, C. J., and D. E. Bauman. 1987. Somatotropin and lactation. J. Dairy Sci. 70:474-486.

Pershing, R. A., M. C. Lucy, W. W. Thatcher, and L. Badinga. 2002. Effects of BST on oviductal and uterine genes encoding components of the IGF system in lactating dairy cows. J. Dairy Sci. 85:3260-3267.

Savio, J. D., L. Keenan, M. P. Boland, and J. F. Roche. 1988. Pattern of growth of dominant follicles during the oestrous cycle of heifers. J. Reprod. Fertil. 83:663-671.

Schiffrin, E. L., F. Amiri, K. Benkirane, M. Iglarz, and Q. N. Diep. 2003. Peroxisome proliferator-activated receptors. Vascular and cardiac effects in hypertension. Hypertension 42:664-668.

Sirois, J., and J. E. Fortune. 1988. Ovarian follicular dynamics during the estrous cycle in heifers monitored by real time ultrasonography. Biol. Reprod. 39:308-317.

Smith, W. L., R. M. Garavito, and D. L. DeWitt. 1996. Prostaglandin endoperoxide $\mathrm{H}$ synthases (cyclooxygenases)-1 and -2. J. Biol. Chem. 271:33157-33160.

Spencer, T. E., A. Gray, G. E. Johnson, K. M. Taylor, A. Gertler, E. Gootwine, T. L. Ott, and F. W. Bazer. 1999. Effects of recombinant ovine interferon tau, placental lactogen, and growth hormone on the ovine uterus. Biol. Reprod. 61:1409-1418.

Spencer, T. E., M. A. Mirando, J. S. Mayes, G. H. Watson, T. L. Ott, and F. W. Bazer. 1996. Effects of interferon-tau and progesterone on oestrogen-stimulated expression of receptors for oestrogen, progesterone and oxytocin in the endometrium of ovariectomized ewes. Reprod. Fertil. Dev. 8:843-853.

Thatcher, W. W., F. F. Bartol, J. J. Knickerbocker, J. S. Curl, D. Wolfenson, F. W. Bazer, and R. M. Roberts. 1984. Maternal recognition of pregnancy in cattle. J. Dairy Sci. 67:2797-2811.

Thatcher, W. W., M. Binelli, J. Burke, C. R. Staples, J. D. Ambrose, and S. Coelho. 1997. Antilutelytic signals between the conceptus and endometrium. Theriogenology 47:131-140.

Van den Bosch, H. 1980. Intracellular phospholipase A. Biochim. Biophys. Acta 604:191-246.

Wu, W. X., J. Owiny, Q. Zhang, X. H. Ma, and P. W. Nathanielsz. 1996. Regulation of the estrogen receptor and its messenger ribonucleic acid in the ovariectomized sheep myometrium and endometrium: The role of estradiol and progesterone. Biol. Reprod. 55:762-768.

Zhao, X., J. H. Burton, and W. McBride. 1992. Lactation, health, and reproduction of dairy cows receiving daily injectable or sustainedreleased somatotropin. J. Dairy Sci. 75:3122-3130. 